\title{
Máté-Szabó Barbara
}

\section{A SPORT ÉS TANULÁS KAPCSOLATA}

\section{A SPORT KÖZÖSSÉGI ÉS TANULÁST FEJLESZTŐ SZEREPE HAJDÚNÁNÁSON}

\author{
DOI 10.35402/kek.2019.2.3
}

\begin{abstract}
Absztrakt
Esettanulmányunkban arra vállalkozunk, hogy megvizsgáljuk, milyen szerepe van/lehet a tanulásnak a hátrányok leküzdésében. A tanulás hogyan járul hozzá egy településrész, település, térség fejlesztéséhez innovatív kezdeményezések által. Elsősorban a kulturális tanulás (Juhász - Szabó 2016) felől közelítettünk, azon belül a sport területét vizsgáljuk, a sport és tanulás kapcsolatának összefüggéseit tekintettük át Hajdúnánás járásban és a járás központjában. Esettanulmányunkban egy kuriózumnak számító kezdeményezés kialakulását és fejlődési vonulatát vizsgáltuk. Egyértelműen megállapítható volt, hogy a „helyi hősöknek” és az ő általuk bevont szereplőknek mekkora értékük és motiváló erejük van a tanulás elindításában, a közösségek formálásában. Eredményeink között az életminőség javítása, életmódváltás, az azzal járó tanulás, illetve a közösségi élményből fakadó tanulás és intergenerációs hatás is meghatározó volt.
\end{abstract}

\footnotetext{
Abstract

Our case study attempts to examine the role that learning can play in overcoming disadvantages. How learning contributes to the development of settlement and region through innovative initiatives. We focused on cultural learning (Juhász - Szabó 2016), within which we examine the field of sport, we have examined the relationship between sport and learning in the district of Hajdúnánás and in the center of the district. In our present case study we examined the formation and development of a curiosity initiative. It was clear that the "local heroes" and the actors they involved had the value and motivating power to start learning, shaping communities. Our results included the improvement of the quality of life, lifestyle changes, the related learning and the learning and intergenerational effects of the community experience.
}

\section{Bevezetés}

Hat éve kezdődött egy komoly kutatási munka, mely Magyarország tanulási atlaszának megalkotását tűzte ki céljául. A LeaRn kutatás alapját a német (ELLI/DLA), és a kanadai (CLI) kutatások, valamint a csoport tagjainak előzetes kutatási eredményei és tapasztalatai alapozták meg. Az elméleti munkacsoport mellett négy dimenzió mentén folytak a vizsgálatok, ezzel is a kialakított LeaRn-index négy pillérét alapozták meg (Kozma et al 2015; Kozma et al 2016). A formális tanulás mellett nem formális tanulás, közösségi tanulás és kulturális tanulás munkacsoport is dolgozott, kiegészülve egy statisztikai munkacsoporttal, akik végül megalkották a munka egészét jelképező tanulási atlaszt.

A kutatás zárását követően a munka nem állt meg, és a kutatók összefogásának köszönhetően a LearnInnov kutatócsoport (Kozma 2018) tagjai arra vállalkoztak, hogy megvizsgálják, milyen szerepe van, illetve lehet a tanulásnak a hátrányok leküzdésében, valamint, a tanulás hogyan járul hozzá egy településrész, település, térség fejlesztéséhez az innovatív kezdeményezések által.

Esettanulmányunkban a hajdúnánási járást vizsgáltuk, elsősorban statisztikai adatok és interjúk gyűjtése révén, a járáson belül pedig kiemelten foglalkozunk a járás központjával, Hajdúnánással. Az Országos Területfejlesztési és Területrendezési Információs Rendszer (TeIR) adatait használtuk, melynek segítségével népességi, és területi jellemzők segítségével jobban tudtuk munkánk során a választott járás és város elemzését elkészíteni. Második kutatási pillérünknek a LeaRn kutatás során elkészült adatbázis, a LeaRn-index szolgált. Emellett terepmunkát is végeztünk. Interjúk segítségével próbáltunk meg választ keresni kérdéseinkre, amit elsősorban a kulturális tanulás felől közelítünk meg. Kulturális tanuláson a Tanuló régiók Magyarországon (LeaRn) kutatás fogalom-meghatározását vesszük alapul (Juhász - Szabó 2016). A kulturális tanuláson belül a sport területét vizsgáljuk, a sport és tanulás kapcsolatának feltárására törekszünk. 
2. Hajdúnánási járás bemutatása társadalmi összetétele alapján

Hajdú-Bihar megyében Hajdúnánási járás a Hajdúhadházi kistérséget megelőzően mind lakosainak számában, mind területében a második legkisebbnek mondható. $547 \mathrm{~km}^{2-e n}$ hat település alkotja a járást: Folyás (288 fó, 54 km²), Görbeháza (2 366 fó, 80 km²), Hajdúnánás (16 908 fó, $260 \mathrm{~km}^{2}$ ), Polgár (7 904 fö, $\left.97 \mathrm{~km}^{2}\right)$, Tiszagyulaháza (698 fó, $21 \mathrm{~km}^{2}$ ), Újtikos (836 fö, $35 \mathrm{~km}^{2}$ ). A 29.000 fót számláló járás a 290/2014. (XI. 26.) Korm. rendelet alapján a kedvezményezett, még a 290/2014. (XI. 26.) Korm. rendelet alapján, illetve a 290/2014. (XI. 26.) Korm. rendelet alapján nem a fejlesztendő és komplex programmal rendelkező járások közé sorolhatjuk.

A népesség az elmúlt tíz évben folyamatosan csökkent, a lakosság nagy százaléka kezd elöregedni, a fiatalok elsősorban a tanulás és munkalehetőségek miatt a megyeszékhely vagy a fôváros felé veszik az irányt.

A 2. ábrán a lakosság létszámának változásait követhetjük 2005-2015 között. Az adatok a járás adatai mellett a megye átlagait, az országos átlagot, az Észak-Alföldi régiót és magát Hajdúnánás várost, tehát a járás központját is bemutatja. Ezzel is kiválóan szemléltetve a járás sajátosságait.

Legutóbb a 2010-es év volt a legrosszabbnak tekinthető a természetes szaporodás, fogyás értékeit nézve, majd egy folyamatos javulás és jelenleg egy stagnálás látható. A megye és a régió tekintetében a járás jóval gyengébb mutatókat produkál, még az országos átlagot nézve egyre jobban közelít hozzá, ha csak az elmúlt éveket vesszük figyelembe. 20052015 között közel 1000 fóvel csökkent a járás lakóinak száma (TeIR, 2018), mely az elmúlt 2 évben is tovább folytatódhatott. A járásban és Hajdúnánáson is lakóhellyel rendelkező munkaképes korúak (18-59 évesek) számából is látható a 3. ábrán, hogy folyamatos csökkenés tapasztalható.

A járásban található népesség fogyása kapcsán fontosnak tartottam a térség munkaerő-piaci mutatóinak bemutatását is. A 2. ábrához hasonlóan a 3. ábrán is az országos, régiós és megyei és a települési adatokat is bemutatjuk a jobb viszonyítás érdekében. A gazdasági válság a járás számára is hatalmas problémákkal járt, az adatok ezért is kiugróak 2009-2011 között. 2007-től kezdődően folya-

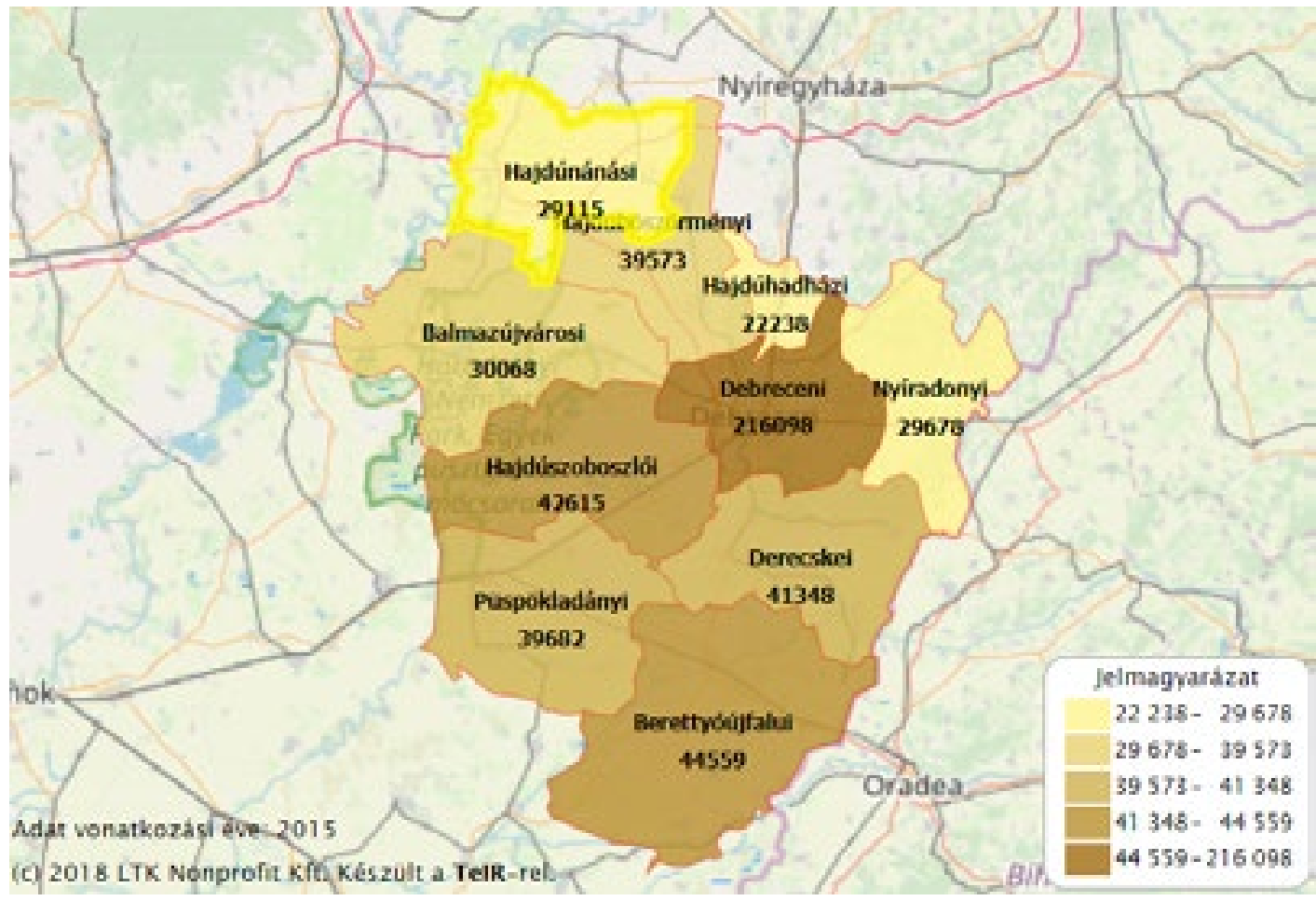

1. ábra Hajdú-Bihar Megye járásai és lakosai száma.

Forrás: teir.hu 
(c) 2018 Lechner Nonprofic Kfr. Kiszolt a TatR-rel.

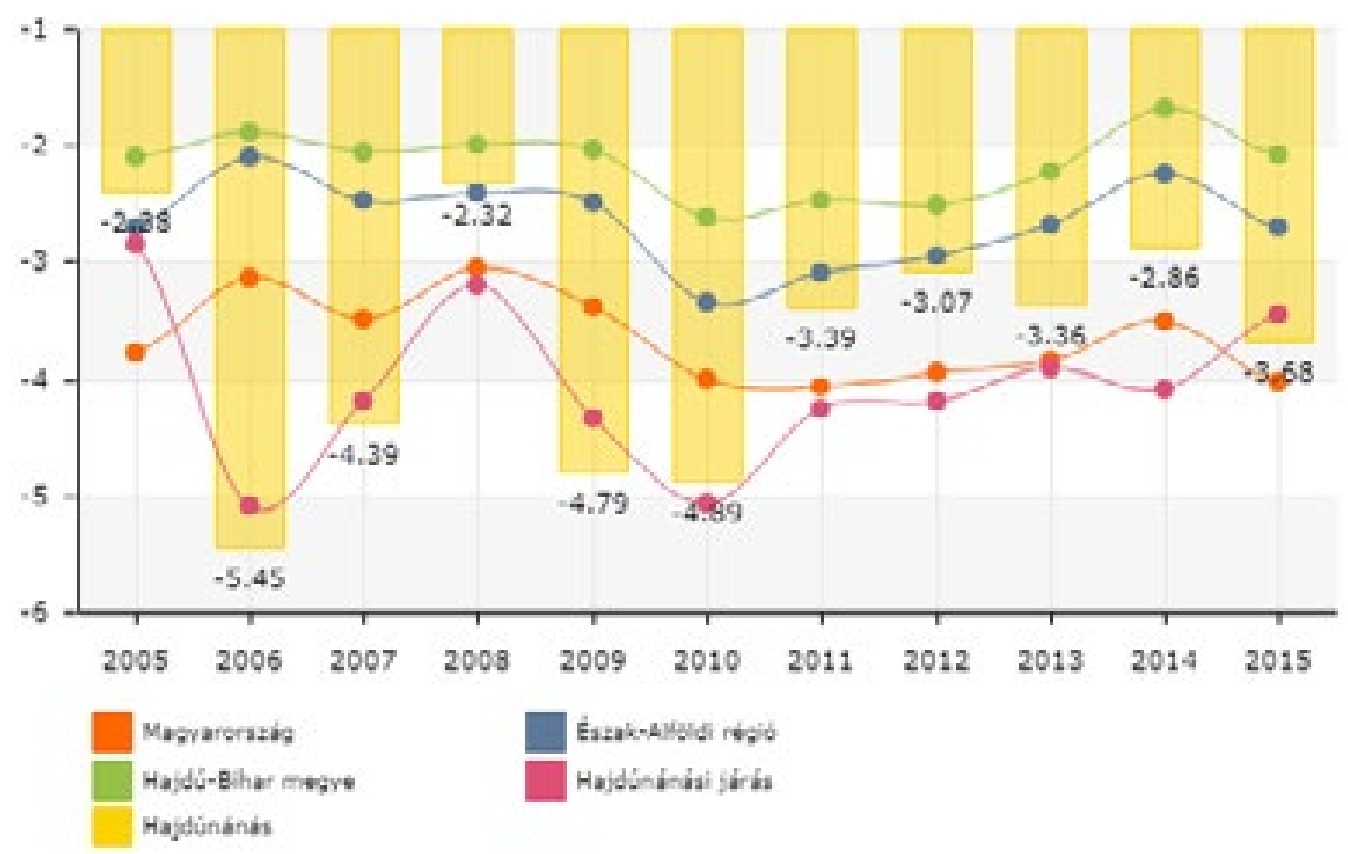

2. ábra Hajdúnánási járás természetes szaporodás/fogyás (ezrelék). Forrás: teir.hu

(c) 2018 Lechner Nanprofit Nft, Kiszilt a TetR-rel.

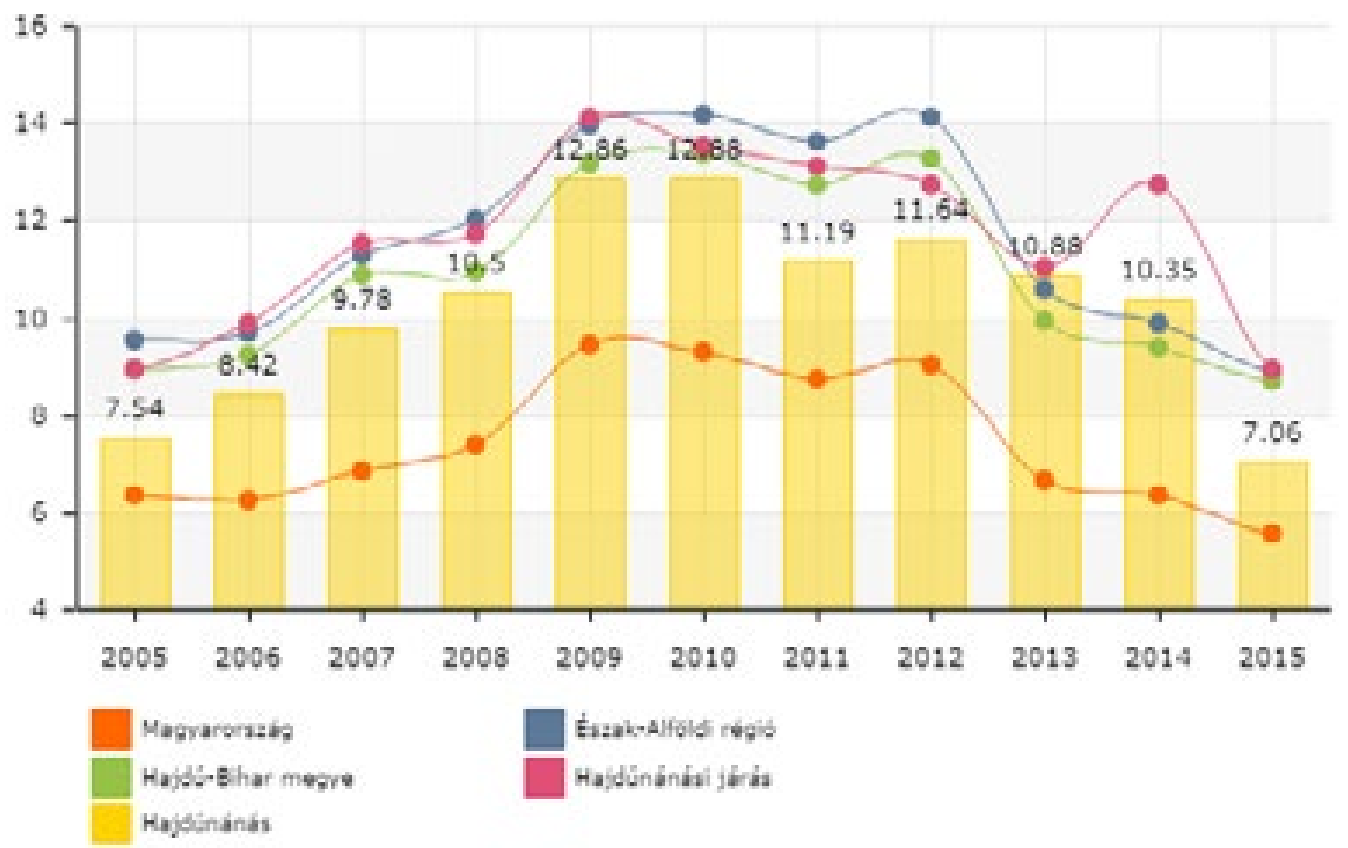

3. ábra Hajdúnánási járás Munkanélküliségi ráta (százalék) Forrás: teir.hu 


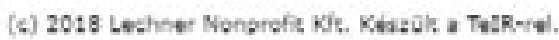

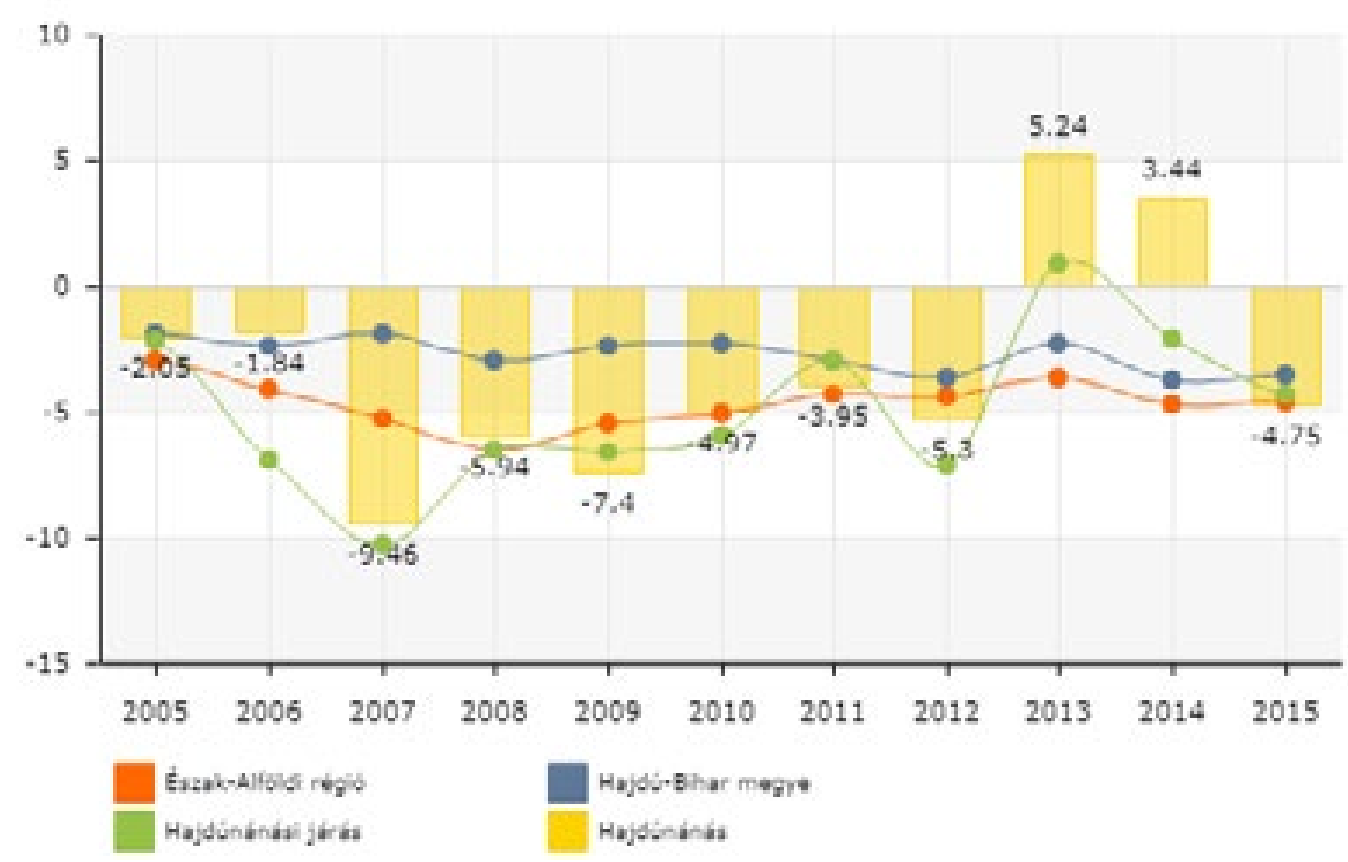

4. ábra Hajdúnánási járás Vándorlási egyenleg (ezrelék) Forrás: teir.hu

(c) 2018 Lechner Nonorofie Kit. Kissut, a TelRerel.

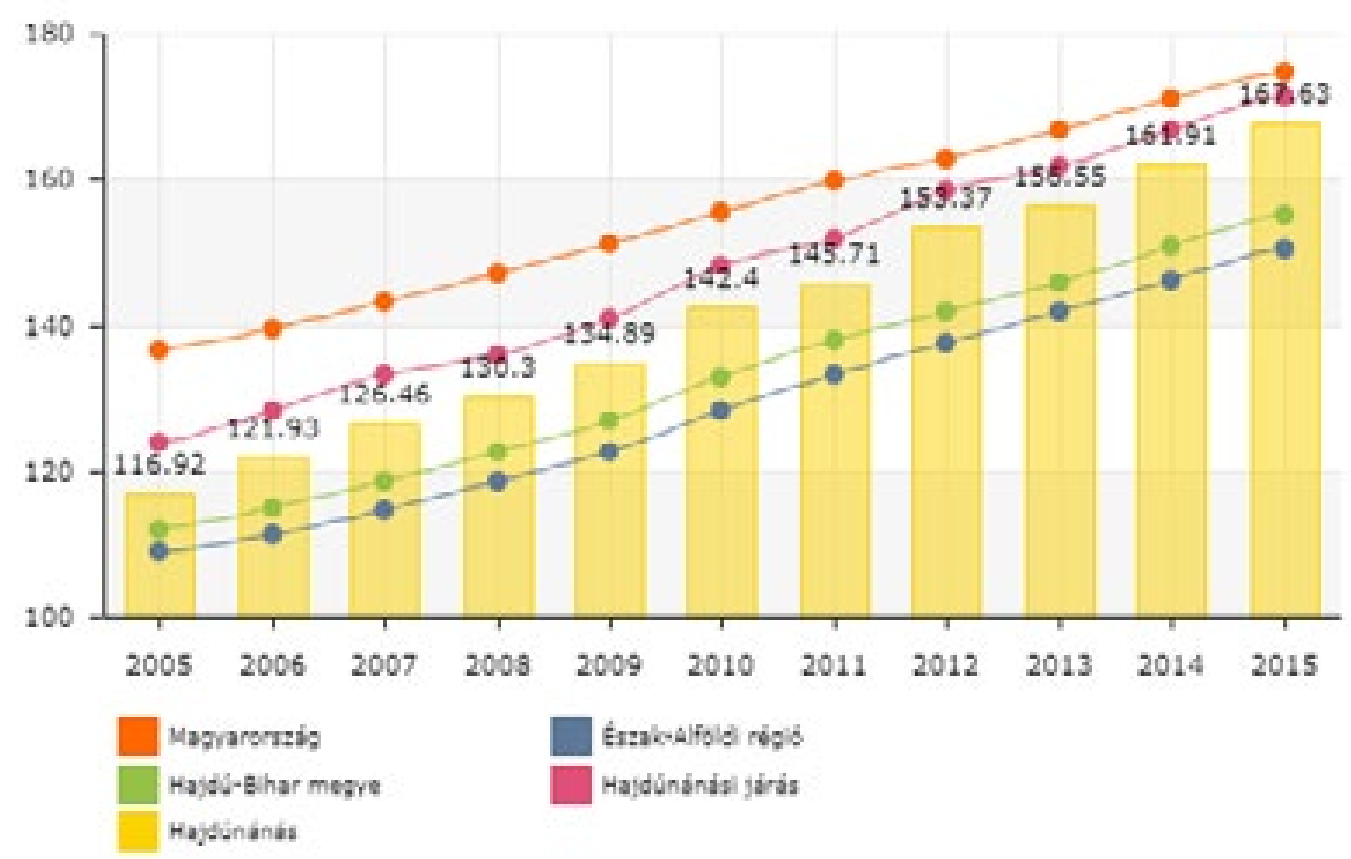

5. ábra Hajdúnánási járás öregedési mutatója Forrás: teir.hu 
matos növekedés volt a munkanélküliek arányában, mely egészen 2013-ban esett vissza a 2006-2007 közötti eredményekre. Látható, hogy az országos viszonyokhoz képest a legfrissebb 2015-es adatokat is nézve, magas a munkanélküliségi ráta. Ugyanez elmondható a megyei és régiós értékekhez képest, hiszen közel azonosan mozognak 10-11-es értéken, még a járás értéke meghaladja ezt 12,69-es eredménnyel. Talán ez az ábra szemlélteti leginkább a járás lakóinak problémáját, a csökkenő lakosság mellett megjelenő munkanélküliségi problémákat.

Az Észak-Alföldi régió és Hajdúnánás járás, illetve Hajdúnánás város vándorlási egyenlegét a megyei értékekkel hasonlíthatjuk össze. A vándorlási különbözet az adott közigazgatási egységbe állandó vagy ideiglenes jelleggel bejelentkezők és az onnan másik közigazgatási egységbe állandó vagy ideiglenes jelleggel bejelentkezők számának különbözete ezer lakosra vetítve (TeIR 2018).

A 4. ábrán jól látható, hogy az elmúlt években mekkora mozgás is volt tapasztalható. Egyértelmüen kirajzolódik az elvándorlások erősödő mértéke, mely a legutóbbi, 2015. évi adatokban $-4,75$ értékekkel szerepel, hasonlóan 2010-hez képest.
A település öregedési mutatóit is megvizsgáltuk, hasonlóan az előzőekhez, viszonyítottuk a megye, járás, a régió és az országos mutatók 2015. évi arányaihoz. Maga a mutató a gyermekkorúakhoz viszonyítva fejezi ki az időskorúak arányát. Az Országos Területfejlesztési és Területrendezési Információs Rendszer az állandó népességből a száz 0-14 évesre jutó 60-x évesek számát összegzi.

Az 5. ábrán jól láthatjuk, hogy folyamatosan növekszik minden összehasonlításban a mutató, de maga Hajdúnánás város és a hajdúnánási járás nem éri el az országos átlagot, viszont a régió és a megye öregedési mutatóitól magasabb eredményeket produkál: 167.63 Hajdúnánás város mutatója, még 155.22 Hajdú-Bihar megye öregedési mutatója.

Fejezetünk utolsó részeként fontosnak véljük, hogy megismerjük a város és a térség regisztrált nonprofit szervezeteinek számát. A 6. ábrán láthatjuk az alapítvány, közalapítvány, egyesület, egyesülés, érdekképviselet, köztestület, közhasznú társaság, valamint az egyesülési törvény hatálya alá tartozó társadalmi regisztrált szervezet számát 2011-2015 között.

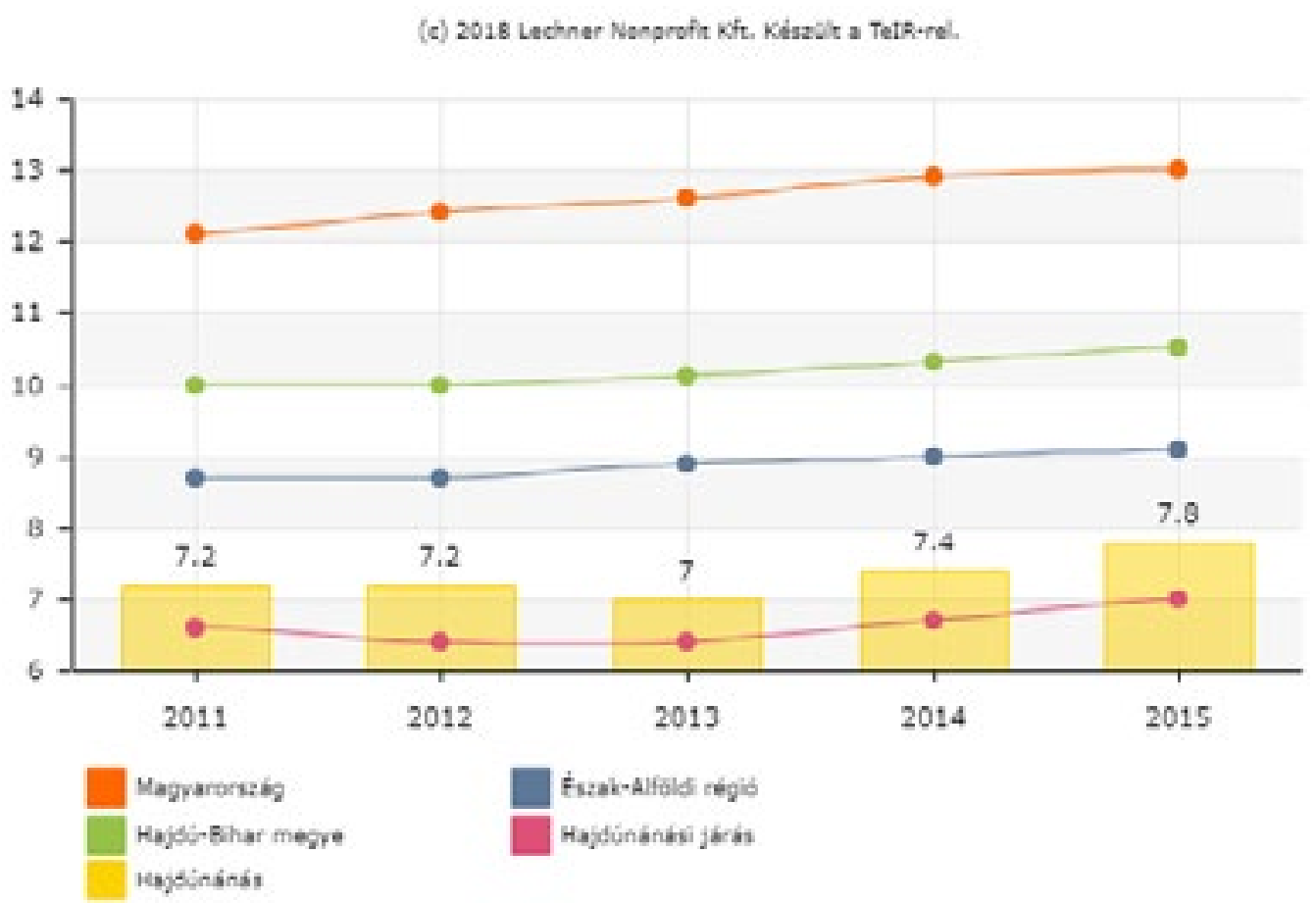

6. ábra Hajdúnánási járás Regisztrált nonprofit szervezetek ezer lakosra jutó száma, 2011-töl (db) Forrás: teir.hu 
Maga Hajdúnánás város jóval elmarad az országos átlagtól, mely ezer lakosra számolta 13 szervezetet jelent. A megyében 10,5, míg az Észak-Alföldi régióban 9,1 szervezet jut ezer lakosra. Viszont a járás átlaga elmarad egy kicsivel a városétól, 7 szervezet jut ezer före.

Az ábrák és rövid elemzésünk segítségével szerettük volna érzékeltetni és bemutatni a vizsgálatunk kiinduló pontjait. Az eredmények egyértelműen rávilágította arra minket, hogy érdemes tovább vizsgálódni, ezért a LeaRn-index segítségével a bevezetőben is ismertetett négy pillért vizsgáljuk.

\section{A LeaRn-index bemutatása a Hajdúná- nási járásban}

Tanulmányunk második részében az élethosszig tartó tanulás kanadai mérései és a német tanulási atlasz alapján készült hazai tanuló régiókat feltérképező indexeket nézzük meg a Hajdúnánási járás viszonyában (Teperics és mtsai 2016).

Az I. pillér esetében a PISA kutatások alapkészségei (olvasás-értés, problémamegoldás, matematikai és természettudományos készségek) és a felnőtt korúak képzései és elért végzettségei szerepelnek súllyal. A II. pillérben (Györgyi - Márkus 2016; Márkus - Juhász 2018) az informális tanulás, felnőttoktatás eredményeit láthatjuk. A LeaRn statisztikai munkacsoportja a III. és IV. pillérben kényszerült a legtöbb kiváltásra a kanadai és német indexek esetében. A III. pillérben a kulturális tanulás mutatói szerepelnek (Juhász 2016). A közművelődési intézmények, médiumok és a sport részvételt tekintve fontos eredményekre mutatnak rá a vizsgált járás esetében. Az utolsó, IV. pillér a közösségi tanulást vizsgálja (részletesebben a nonprofit szervezeteket, a vallási aktivitást, és a kisebbségi önkormányzatokat). Az index utolsó alapvető összetevője a vándorlási egyenleg értékei voltak a 2001-2011 közötti időszakban. Látható, hogy igen magas ez a százalék, mint ahogyan a lakosság elemzésénél kitértünk már erre a tanulmány elején is. Utolsó táblázatunkban az eddig kicsit részleteiben bemutatott indexeket összevontan láthatjuk. A vizsgált Hajdúnánási járásba hat település tartozik.

Az 1. táblázatunkban a járás településeinek pilléreit és a komplex pillér index-értékeit láthatjuk. A vizsgált Hajdúnánási járás hat települését a jobb összehasonlíthatóság érdekében az országos eredményekkel együtt illesztettük be táblázatunkba. A négy pillér mellett a komplex értéket is láthatjuk. Egyértelműen az I. és a IV. pillér eredményei dominálnak.

Az 1. pillér esetében látható, hogy a járás központjának számító Hajdúnánás nem az elsők között szerepel a hat település rangsorában, mégis az országos átlag felett van. Emellett a kapott indexek háttérmutatói megmutatták, hogy alacsony a 10 évnél idősebb népesség tekintetében az egyetlen osztályt sem teljesítők aránya, ezzel szemben a legalább általános iskolai végzettséggel vagy érettségivel és diplomával rendelkezők átlaga már nem mondható magasnak.

A 2. pillér esetében két településnél nincs adatunk. A másik négy település eredményei erőteljesen mutatják a térségben megjelenő informális tanulás szerepét, bár a lakosság arányában a felnőttképzéseket befejezők aránya alacsony átlagú.

A kulturális tanulást vizsgálva az átlagot csak Polgár közelíti meg, itt elmaradnak a járás települései az átlagtól, hasonlóan a 4. pillérhez. A háttéradatokból látható, hogy a helyi médiumok száma 1000 lakosra nézve nagyon alacsonynak mondható. A művelödési formákban történő rendszeres részvétel nem éri el az 1\%-ot. A nonprofit szervezetek 1000 lakosra jutó aránya nagyon csekély a járásban, ez is mutatja a civilek hiányát. Átlagában nem éri el az 1\%-ot. A különböző művelődési formákban

1. táblázat: Összevont index eredményei a Hajdúnánási járásban

\begin{tabular}{|c|c|c|c|c|c|}
\hline & Pillér I. & Pillér II. & Pillér III. & Pillér IV. & Komplex pillér \\
\hline Folyás & 61.02 & 0.0 & 3.65 & 28.04 & 23.17 \\
\hline Görbeháza & 55.44 & 10.89 & 6.19 & 31.30 & 25.95 \\
\hline Hajdúnánás & 56.26 & 23.12 & 6.71 & 29.15 & 28.81 \\
\hline Polgár & 61.28 & 13.97 & 7.10 & 32.50 & 28.71 \\
\hline Újtikos & 51.28 & 9.56 & 4.06 & 30.40 & 23.82 \\
\hline Tiszagyulaháza & 52.35 & 0.0 & 1.08 & 33.70 & 21.78 \\
\hline Magyarország & $\mathbf{5 3 , 8}$ & $\mathbf{8 , 8 4}$ & $\mathbf{7 , 4 1}$ & $\mathbf{3 6 , 3 9}$ & $\mathbf{2 6 , 6 1}$ \\
\hline
\end{tabular}


történő rendszeres részvétel aránya szintén hasonló, ezek szerint az erre való igény is eléggé alacsony lehet. A vallási aktivitást nézve, melyben a statisztikusok az 1000 lakosra jutó hívők számát mérték meg, látható egy jóval erősebb aktivitás, mint a civilek esetében. A lakosság több mint 50\%-a vallásos a járásban. Összességében az összevont komplex index országos átlagát Hajdúnánás és Polgár is felülmúlja.

\section{Az interjúk tanulságai}

A közösségi tanuláson belül a sportéletet és a sport közösségformáló szerepét vizsgáltuk a járásban. Előzetes adatgyüjtésünk során kiderült, hogy a járás központjában találkozhatunk a legtöbb sportággal. Hajdúnánás az elmúlt 20 évben rengeteg változáson ment keresztül a sportot támogató infrastruktúra tekintetében, egyesületek alakultak, szakembereket hoztak a városba. Kiemelt sportágak között szerepel a város életében a futball, kézilabda, úszás, karate, kendo, kajak-kenu és a birkózás. Jelen tanulmányunkban egy olyan sportág meghonosodását, közösségi és tanulást fejlesztő szerepét vizsgáljuk, mely a város életében igen meghatározó, rengeteg gyermeket, családot mozgat meg napról napra, sőt eredményeik országos szinten is kiválóak, kiemelkedők.

A kajak-kenu sportágban dolgozó szakemberekkel, egyesületi vezetőkkel készített interjúk tapasztalataiból láthatóvá vált, hogy a sportélet és a közösségi tanulás mennyire is meghatározó a város és a járás életében. Egyrészt a városvezetők, vállalkozók a sportágat kiemelten támogatják, sőt a látvány sportok között is országosan támogatott sportágakként támogatásokat kap az egyesület.

A járásban kuriózumként jelent meg 2011-ben a kajak-kenu sportág. Az akkor iskolai sportkörként létrejött közösség két év alatt önálló egyesületté nőtte ki magát, és 2013-tól a Magyar Kajak-Kenu Szövetség innovatív tagszervezetévé vált. A település minden segítséget megadott a kezdeti lépésekhez: használatra átadta a Keleti Főcsatorna partján lévő egyik területét, illetve a Hajdúnánási Gyógyfürdő egykor szebb napokat átélt Csónakázó tavát jelölte ki a célra, amely kb. 500 méteres, 1-1.2 méter mély kis vízi körpálya és 30-35 fokos termálvíz táplálja a nap 24 órájában. A települési önkormányzat segítségével került sor a tó és környezetének szükséges rehabilitációjára, kotrásokra, iszaptalanításra, a környezet rendezésére, stég kialakítására, majd egy csónakház felépítésére. Az addig használaton kívüli terület így vált alkalmassá több közösségi rendezvény helyszínéül is, és a későbbiekben egy igazi fesztiválterületté nőtte ki magát. Kezdetben a kajak-kenu egyesület feladata volt ezt a területet közösségi élettel megtölteni, de hamarosan csatlakoztak más civil szervezetek is, hiszen újabb innovatív kezdeményezések kerültek napvilágra.

„Alapvetö célunk volt a vidéki fenntartható életmód és az ehhez kapcsolódó pozitiv viselkedésminták gyakorlat közeli átadása és annak közös élményként való átélése, természeti és társadalmi értékeink megismertetése, elterjesztése, a környezettudatosság, környezetkultúra és környezet-etika fejlesztése a mindennapi élet területén. További célunk volt még a hozzáférés biztositása a fiatalok számára a természeti és környezeti fenntarthatóság tanulásának nem iskolai formáihoz" (egyesületi vezetö).

Sokan nem gondolták az elején, hogy két-három évet követően több gyermek korosztályos országos bajnok tudott lenni, sőt korosztályos válogatott is. Érezhető volt az interjúkat követően, hogy egy jó ötletből, egy megfelelő közösségi szellemben, hogyan lehet megteremteni egy sikeres sportágat, egy új közösségi lehetőséget. A közvetlen célcsoportok elsősorban a gyermekek és fiatalok, azaz a felnövekvő nemzedék - HDDSE sportolói, valamint az egyesületnél rendszeres közszolgálati tevékenységet vállaló középiskolások.

„A kajak-kenu-sárkányhajó nemcsak a gyermek számára egy remek lehetöség, vannak masters korú sportolóink is, tehát a szülök a rengeteg támogatás és segitség mellett, a gyermekekkel közösen tudnak edzeni, sportolni az egyesületünkben" (egyesületi vezető).

A lehetőségeket figyelve a pénzügyi háttér adott, mindenki próbálja a részét beletenni fóként az utánpótlás fejlesztésébe, a gyermekek támogatásába, hogy minél több gyermek tudjon versenyezni és megismerkedni a vizes sportággal.

Nagyon fontos eleme a versenyeztetésnek a közösség hozzáállása. A szülői és oktatási intézmények támogató szerepe. Látható, hogy a családi háttér és támogatás rengeteget jelent, fóként az utánpótláskorú gyermekek számára, ahogyan fogalmazott az egyesület vezetője is: „A fenntartható egészség- és környezettudatos vidéki életmódhoz kapcsolódó viselkedésminták elterjesztése mindannyiunk érdeke, mint ahogyan a felnövekvö nemzedék életmódja is. A gyermekeink szocializálódása nem mindegy, hogy milyen környezetben történik. A kajak-kenu sport természet közeli helyszinen létezik, sok egyéni munkára, küzdésre, kitartásra nevel, valamint alkalmazkodásra, igy csapatmunkára is tanit. Az ebben a sportágban 
felnött sportolók általában az élet más területein is helyt állnak, értékei lehetnek jövönk társadalmának" (egyesületi vezetö).

Az edzők egyöntetü véleménye alapján a rendszeres edzések, a versenyek egyfajta rendszert visznek a sportolók életébe. A tanulást és a hétköznapi iskolai megmérettetésekre való felkészülést nagyban segítik, ha a gyermekeknek az évek folyamán kialakul egyfajta rendszer az életükben. A tanulásban és a tanulmányi versenyekben a sportolók döntő többsége kiváló eredményeket ér el, melyre a szülők is büszkék lehetnek.

Több esetben is felmerült a járás megtartó ereje, hiszen általános és középfokú intézmények vannak a városban és a környezö településeken, de az általános iskolát befejezve, vagy az érettségit követően - a továbbtanulás miatt - a fiatalok többsége elhagyja a települést és ezzel együtt a rendszeres edzési alkalmakat. Egyrészt a munkalehetőségek is korlátozottak a járásban, másrészt (sok esetben) az életvitelszerü sportolóvá válás is közrejátszik abban, hogy a középfokú tanulmányait is a gyerekek 5-10\%-a már máshol végzi el. Az egyesület nem tud versenybe szállni olyan földrajzi adottságokkal, melyeket a Tisza vagy Duna partján lévő, nagymúltú egyesületek adhatnak, viszont megtalálta helyét azokban a szerepekben, mint a generációk közötti szoros közösségi összetartozás, egészséges életvitel kialakítása, valamint az országos utánpótlási nevelő tevékenység kiépítése.

Fejlesztési célok között az interjúk rávilágítottak arra, hogy az infrastruktúra folyamatos javítása egyre jobban elengedhetetlen, emellett a fiatalok helyben tartása és a közösségek építése is fontos cél a város vezetése számára is.

„A nánási turizmus hosszú távú eredményességének egyik záloga lehet a kajak-kenu sport helyi bázisa, mely megnyilvánulhat a természeti és társadalmi környezet értékeinek megörzésében, és a helyi humáneröforrások e célnak való megfeleltetésének feltérképezésében, illetve további lehetöségek kiaknázásában, fejlesztésében" (egyesületi vezetö).

Az egyesület vezetőjével készített interjú során meglepően tapasztaltuk, hogy a generációk menynyire bevonódnak a sportág segítésébe. A szülők mellett a nagyszülők is rengeteget tesznek a közösségért, az együtt tanulásért.

A generációk közötti tanulást, a gyermekek fejlődését is nagyban segíti a szülői hozzáállás, támogatás, sokszor az anyagi befektetés is, hiszen a gyermekek utaztatásában, versenyeztetésében is sokat segítenek a szülők, akár egymáson is, sőt az edzők nagy örömére, akár még családi rendezvények gyanánt a hazai versenyeken fózéseket, családi napokat, fakultatív programokat is szerveznek.

„Azt gondoljuk, hogy helyi közösségként (Hajdúnánási Dominó DSE tagjai, sportolói, azok családjai és egyéb támogatói) a természet közelsége, megismerése iránti vágy, az egészséges életmód és a rendszeres munka igénye alapvetö kritérium, valamint ahol több generáció együttes tevékenysége már több sikeres együttmüködés és közösségi rendezvény záloga" (egyesületi vezetö)

Hatalmas szerep hárul a tanulás kapcsán a megfelelő időtervezésre, a gyermekek eredményes iskolai szereplésére is. „A kettö csak együtt müködhet? - fogalmazott az interjúk során a kajakosok egyik edzője.

A közösségi összefogás, együtt tanulás mellett az ismeretszerzésre, élményekre is nagy figyelmet fordítanak az egyesületben. A londoni Olimpiát követően több olimpiai bajnok és olimpikon is meglátogatta az egyesület vezetőit és a gyereket. Többször tartottak már előadásokat, bemutatókat a gyerekeknek és szülőknek egyaránt, mely tovább erősítette a kapcsolatot a sport és a versenyzők között. Söt rendezvényeiken továbbra is jelen vannak a sportág jeles képviselöi, olimpikonjai.

„Segitöink, támogatóink még olyan országosan, söt nemzetközileg is elismert, elsösorban kiemelkedö sporttevékenységük által népszerü emberek, akiket szintén példaként tisztelnek gyerekeink" (edzö).

Az élményszerű tanulás mellett érdekes tényként figyeltünk fel arra az interjúk készítésénél, hogy a helyiek összefogása mennyire meglepte, és cselekedetekre, támogatásra késztette már több alkalommal a Kajak-Kenu Szövetséget és az elismert élsportolókat. Több gyermek hajója, lapátja is e körök anyagi felajánlásának köszönhetően kerültek beszerzésre, így tudott több esetben is fejlődni az egyesület, és vele együtt közel 100 gyermek tudott már megismerkedni a sportággal, sőt a sportág alapjait képező biztonságos úszással is, hiszen minden gyermek számára kötelező megtanulni úszni, mielőtt komolyabban kezd el foglalkozni a sportággal. Számtalan pályázati lehetőségre, azok megragadására van szükség, hogy egy ilyen kisegyesület működhessen, az innovatív fejlesztésekhez pedig további források bevonása is szükséges.

Láthatóvá vált, hogy a szülők és a település lakóinak bevonásával miként is válik a sport a közösségépítés és a közösségi tanulás kulcsszereplőjévé. Egy úgynevezett „helyi hős”, valamint megfelelő anyagi támogatás és befektetés rengeteg család és legfőkép- 
pen gyermek életét változtathatja meg, és a közösségeken belül új folyamatokat tudnak elindítani a tanulás érdekében.

„Az általunk képviselt sportág a fenntartható fejlödés elérésének kérdésében kiemelt jelentöséggel bir, hiszen a szabadidö minöségi eltöltésén keresztül szélesebb rétegben is szolgálja az életminöség javitását, hozzájárul a helyi közösségek jólétéhez, alkalmat teremt egy szélesebb közösség életmódjavitása felé, ugyanakkor kölcsönhatásban áll a természeti, kulturális és épitett környezet állapotával, mely turisztikai vonzerö is lehet a település számára" (egyesületi vezető).

\section{5. Összegzés}

Esettanulmányunkban arra vállalkoztunk, hogy a hajdúnánási járásban nézzük meg a LeaRn index mutatóit, elemezzük és feltérképezzük a kulturális tanuláson belül a sport szerepét. Megpróbáltunk a járás sajátosságaira is röviden kitérni munkánk első részében.

Kutatásunk első fázisában a rövid statisztikai összefoglaló mellett a LeaRn Tanuló régiók kutatás során készített indexeket az alapeloszlások tekintetében megnéztük. Az értékek mögöttes tartalmát szerettük volna jobban értelmezni interjúink során a járás esetében. Egy éppen csak meghonosodó sportág esetében készítettünk interjúkat edzőkkel, egyesületi vezetőkkel. Az eredmények erősen hangsúlyozták a közösséggé válás alapvető feltételeit, illetve azt, hogy a sport miképpen is tud hozzájárulni a tanuláshoz, a gyerekek és szülők testi és szellemi, illetve lelki fejlődéséhez, az életminőség javításához, életmódváltáshoz. Sőt az ezekkel járó tanulás mindenhol jelen volt.

Interjúink egyértelműen a közösségi élményről, az ezekből való építkezés és tanulás lehetőségeiről számoltak be. Az eddigi interjúk adatai alapján egyértelműen megállapítható, hogy a „helyi hősöknek", kezdeményezőknek és az általuk bevont szereplőknek mekkora értékük és motiváló erejük van a tanulás elindításában, közösségek formálásában. Sőt a vizsgált sportágunk formalizálódni is tudott egyesületi formában, tehát nincsen profitorientáltság a vezetők részéről.

$\mathrm{Az}$ intergenerációs hatás nagyon erősen mutatkozott a kajak-kenu sportágban. A gyerekek voltak az elsődleges célcsoport, de a felnőttek és a nagyszülők is bevonódtak és kialakult egy master közösség. $\mathrm{Az}$ egyesület életében a sok-sok együttműködés és szövetségi támogatás nagyban hozzájárult a fejlö- déshez és fenntarthatósághoz. Maga a közösségi média és annak hatása pedig felértékelödött.

A legújabb nevelési-oktatási koncepciókban, napjainkban, kiemelt hangsúlyt kell fektetni a nem formális és informális tanulási módszerek alkalmazására, hiszen ezt a "mai gyerekek=generációk” tanulás iránti motiváltságának fejlesztése érdekében fontos meglépni!

\section{Felhasznált irodalom}

Zoltán, Györgyi - Edina, Márkus 2016 Nonformal Learning: Learning out side the School. In Tamás, Kozma ed. Learning regions in Hungary: from theory to reality. Tribun EU, Brno, 57-71.

Erika, Juhász 2016 Cultural Learning. In Tamás, Kozma ed. Learning regions in Hungary: from theory to reality. Tribun EU, Brno, 72-92.

Juhász Erika - Szabó József 2016 Kulturális tanulás: a tanulás új dimenziója. Educatio 25 (2):198-209.

Kozma Tamás és mtsai 2015 Tanuló régiók Magyarországon - az elmélettól a valóságig. Régió és oktatás IX. CHERD-H, Debrecen.

Tamás, Kozma et al 2016 Learning Regions in Hungary: From Theory to Reality. Tribun EU, Brno

Márkus Edina - Juhász Erika 2018 Learning Regions in Hungary (LeaRn) - The Dimension of Non-formal Learning. Hungarian Educational Research Journal (HERJ), 123-126. DOI:10.14413/HERJ/8/2/10

Teperics Károly - Szilágyiné Czimre Klára - Márton Sándor 2016 A tanuló városok és régiók területi megjelenése és társadalmi-gazdasági mutatókkal való kapcsolata Magyarországon. Educatio 25 (2):245-259.

\section{Internetes források}

Kozma Tamás 2018 Társadalmi tanulás és helyi innovációk. On-line: (2018.12.07-i letöltés) ResearchGate, https://www.researchgate.net/ publication/324840861

Országos Területfejlesztési és Területrendezési Információs Rendszer (TeIR) (2018.12.18-i letöltés, TeIR https://www.teir.hu/helyzet-terkep/ 


\section{Interjúk}

Egyesületi vezető, 2017 A szerző interjúja [Interjú] (10. 12. 2017).

Edző, 2017 A szerző interjúja [Interjú] (14. 12. 2017).

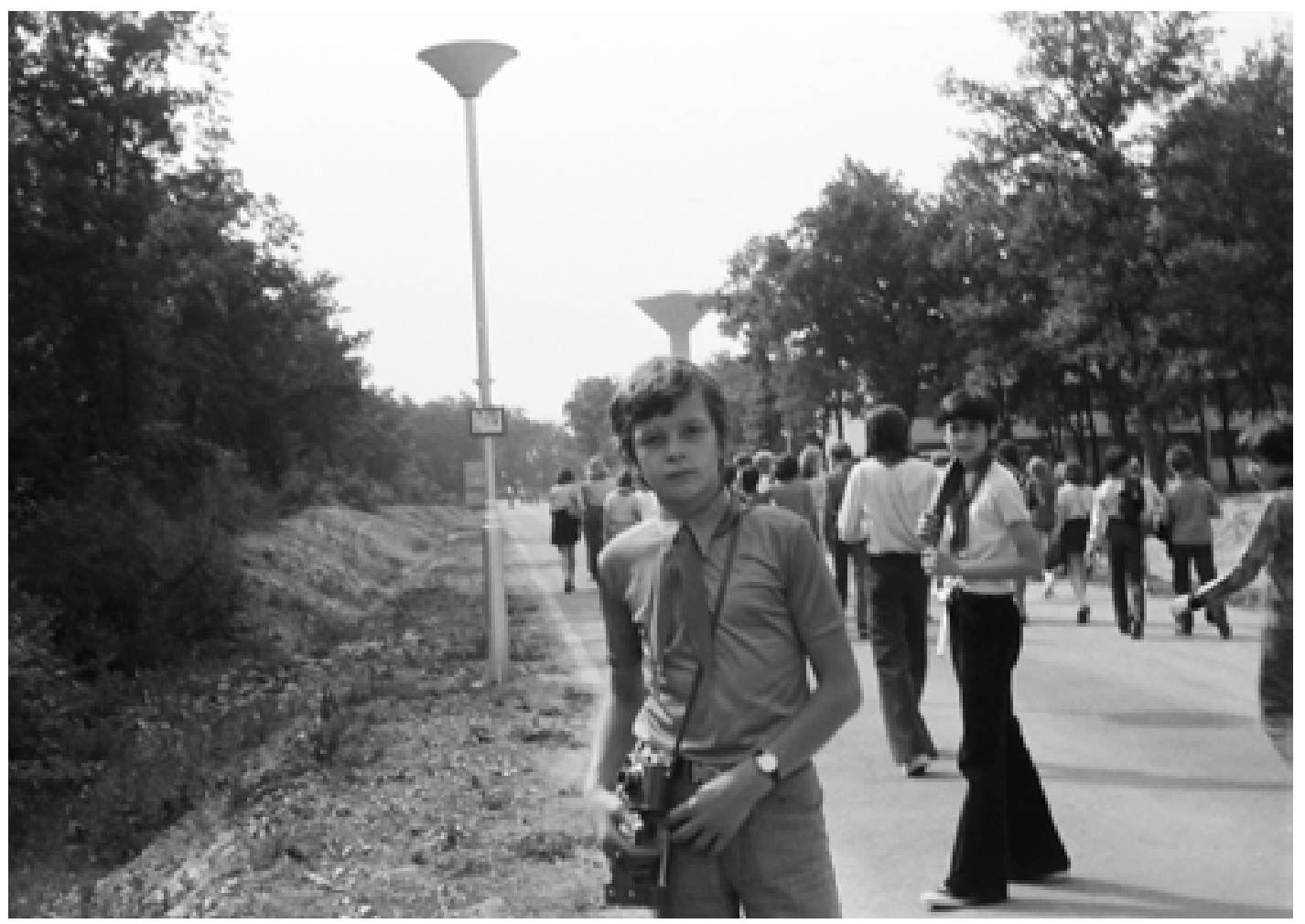

